Editorial

\title{
Editorial: Freedom of Expression and the Online Abyss
}

\author{
Maria Elliot and Kristoffer Holt * \\ kristoffer.holt@Inu.se (K.H.) \\ * Corresponding author \\ Submitted: 29 September 2020 | Published: 15 October 2020
}

Department of Media and Journalism, Linnaeus University, 39182 Kalmar, Sweden; E-Mails: maria.elliot@Inu.se (M.E.),

\begin{abstract}
This introduction to the thematic issue Freedom of Expression, Democratic Discourse and the Social Media discusses the state of the debate surrounding freedom of expression in the field of communication studies and presents four original articles dealing with freedom of speech in contemporary media from different perspectives.
\end{abstract}

\section{Keywords}

democratic discourse; freedom of expression; social media

\section{Issue}

This editorial is part of the issue "Freedom of Expression, Democratic Discourse and the Social Media" edited by Maria Elliot (Linnaeus University, Sweden) and Kristoffer Holt (Linnaeus University, Sweden).

(C) 2020 by the authors; licensee Cogitatio (Lisbon, Portugal). This article is licensed under a Creative Commons Attribution 4.0 International License (CC BY).

Pivotal throughout the history of thought leading up to the liberal modern construals of freedom of expression, was always the notion of man's potential for selfabstraction and self-control in the face of offensive content, vulgarity, repulsiveness, evil, and blasphemy (Peters, 2005). The justification for tolerating such things was always that debate about what is best for the common good would suffer if all perspectives were not given voice. According to Peters, such classical, "heardhearted" liberalism is becoming increasingly difficult to champion in times of increased globalization, cultural pluralism, and postmodern uncertainty. The dilemma of our times is to find a way to reconcile "critical liberty and orthodox faith under postmodern conditions" (Peters, 2005, p. 292). The Mohammad cartoon crisis in 2005 (where caricatures of the prophet Muhammad were published in the Danish daily Jyllands-Posten and caused worldwide protests, resulting in numerous deaths) became a gruesome illustration of Peter's point. Since then, the issue of freedom of expression has continued to be intensely problematized.

With the advent of social media, the very conditions for democratic discourse changed in several ways. New forums for political debate have evolved, forums that are governed by different norms and rules than those of the pre-digital media world. Even though the possibility for the public to actively partake in the public debate has increased significantly (Neubaum \& Krämer, 2017), actual participation still tends to be limited to certain groups and factions. The discourse of social media is governed by a logic of its own, different from the logic that we know from traditional media. However, the ramifications of this are not restricted to the online world-they spill over on traditional media, for instance through the dissemination of false stories or when overinflated storms of opinion get turned into regular news. Furthermore, this is taking place in a social and political context that in many Western societies is undergoing an increasing political and cultural polarization which is picked up by different groups on social media where it gets amplified and sometimes distorted. This interaction between traditional democratic discourse, social media, and the political climate has altered the conditions for expressing different opinions and ideas in the public sphere. This discussion is, however, not only held in relation to various online excesses $(\mathrm{Ng}, 2020)$ but also in connection with offline settings: Cancel culture, no-platforming, and violent protests surrounding controversial speakers have become a recurring phenomenon at universities and deliberative spaces worldwide (Norris, 2020). Such conflicts 
are emblematic of the culture-war-character of today's public discourse.

Amidst online disinformation, alternative news providers, and information warfare, legislators are seemingly at loss over how to handle the situation. We see attempts from various governments attempting to tackle the challenge of disinformation and hateful content on the one hand (Germany making it unlawful to post hate speech in social media, and in France, where it is now illegal to publish 'fake news'), and examples of government initiatives which try to counter activist involvement in universities and the media, on the other hand (Poland and Hungary). The dilemma Peters wrote about in 2005 is even more real today and questions are hanging in the air that need to be addressed from a scholarly perspective. There seems to be a substantial unity, for example, among politicians, journalists, and researchers about the need to work actively against fake news and disinformation. But how will such initiatives materialize, and what implications will they have for the future? While there is a vigorous debate online about freedom of speech, the threat of cancel culture and woke activism on the one hand, and about hate speech, threats to journalists, scholars, and politicians on the other, media scholars tend to be rather absent in the discussion. This thematic issue has its genesis in discussions about these changing conditions, and the consequences these changes may have. The articles approach the problem of freedom of expression, democratic discourse, and social media from several different angles: Internet governance, populist Internet activism, online harassment, and cancel culture.

Digital media has brought about new conditions for public discourse, in particular platforms where users are able to remain anonymous. Examples abound of extremist propaganda, threats, and personal attacks. Legislators are asking for intervention by the social media companies, but seem to be reluctant to alter existing legal provisions for the freedom of expression. Ricknell (2020) explores the future of freedom of expression on the Internet by discussing different possible scenarios of Internet governance and their outcomes for democratic participation, digital surveillance, and free access to media content. She identifies three types of primary players: governments, private tech companies, and users. In her article, she discusses the consequences of each of these governing the Internet infrastructure and hence regulating the content on different platforms. She concludes that user governance, or decentralization, holds the most promising future for freedom of expression and democratic participation on the Internet, even if this scenario also has some pitfalls. She takes a more pessimistic view on the prospects for digital democracy if the Internet were governed by state regulation or by private tech companies. In these cases, censorship, Internet shutdowns, lack of transparency, and restrictions on public access to media could become an increasing problem, not only in countries with authoritarian regimes but also in those traditionally considered to be democratic.
Nevertheless, digital platforms still hold great potential as channels for oppositional political communication, even in countries where freedom of expression is curtailed. Glazunova (2020) illuminates this with her study of the Russian oppositional politician, Alexei Navalny, who uses social media as a channel to reach the public with his anti-corruption investigative journalism and populist message. Glazunova considers Navalny to be an exception in the political life of Russia today, a nonelected opposition activist who has not only survived in the political arena but also been successful at keeping in touch with the public in an oppressive political climate (the article was written before Navalny was poisoned in August 2020).

Public discourse in the media, both legacy media and digital platforms, can be a democratic resource, but it can also be turned into a force aimed at cancelling public figures. Latif (2020) looks into one example of cancel culture in the US in 2019 when an American Muslim scholar was included in a state commission under the Trump administration. Latif's analysis of opinion editorials that was published in the mainstream press as a response to this appointment shows that a substantial proportion of the editorials written by members of the Muslim community could be labelled as character cancellation. Latif also discusses the consequences of opting to be silent or absent on the digital platforms where much of the debate that followed took place.

The public sphere is not constituted by the news media alone. Other genres, like fiction, biographies, and essays, are also nurturing the democratic discourse as well as being dependent on a free and pluralistic public sphere. For this reason, Wegner, Prommer, and Seidel (2020) consider online harassment targeting nonjournalist writers as just a serious threat to democratic discourse as harassment targeting journalists. In their study of German writers, Wegner et al. (2020) found that half of the respondents have personal experience of being harassed online. For many of these, the attacks have resulted in restrictions in their everyday working life in terms of different forms of self-restraint and even selfcensorship. The authors point out that this could have severe consequences for the digital public sphere since they argue that unrestrained literary work is necessary for social inclusion, integration, and plurality.

While limited in scope, the articles in this thematic issue, each in their own way, provide relevant and original contributions to the ongoing debate. Ricknell (2020) provides a constructive framework that allows for a structured discussion of the possible scenarios. Glazunova's (2020) analysis of a Russian case is original since the current research trend within media and populism is to focus on the rise of populist politicians in democratic Western countries (Krämer \& Holtz-Bacha, 2020). Glazunova's analysis shows that alternative media platforms can serve important political and ideological purposes in certain media landscapes, while at the same time being a channel for populist messages, targeting a 
corrupt elite. Latif's (2020) contribution also addresses a complex and sensitive question from an unusual perspective for media scholars: What public positions are realistically available for Muslim intellectuals in America today? It describes the dynamics of cancel culture that should be taken more seriously by the community of media scholars. Wegner et al. (2020) emphasize the fact that it is not only journalists who are put in harm's way, the silencing of other voices is indeed a reality and is equally harmful and problematic.

As an area of interest to media scholars, issues such as these deserve further attention.

\section{Acknowledgments}

The academic editors of this thematic issue would like to thank all the reviewers for their time and effort, wise comments, and helpful suggestions.

\section{Conflict of Interests}

The authors declare no conflicts of interest.

\section{References}

Glazunova, S. (2020). 'Four populisms' of Alexey Navalny: An analysis of Russian non-systemic opposition discourse on YouTube. Media and Communication, 8(4), 121-132.

\section{About the Authors}

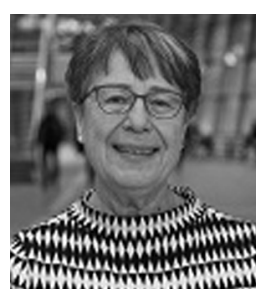

Maria Elliot holds a PhD in Mass Communication and Journalism and is a Senior Lecturer in Media and Communication Studies and Journalism Studies at the Department of Media and Journalism, Linnaeus University, Kalmar, Sweden. Elliot's main research areas are public confidence in the news media and digital news consumption.

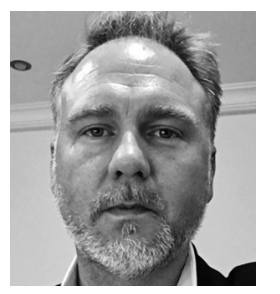

Kristoffer Holt is Associate Professor at the Department of Media and Journalism, Linnaeus University, Kalmar, Sweden. Holt has done research and published about topics related to media as a platform for public discourse. His publications have dealt with alternative media, media criticism, media ethics, citizen and participatory journalism, and media and religion, among other topics. His work has appeared in Digital Journalism, New Media \& Society, European Journal of Communication, Information, Communication \& Society, Journalism Practice, and Javnost: The Public Media and Communication, among others. The title of his latest book is Right-Wing Alternative Media (2019, Routledge). 